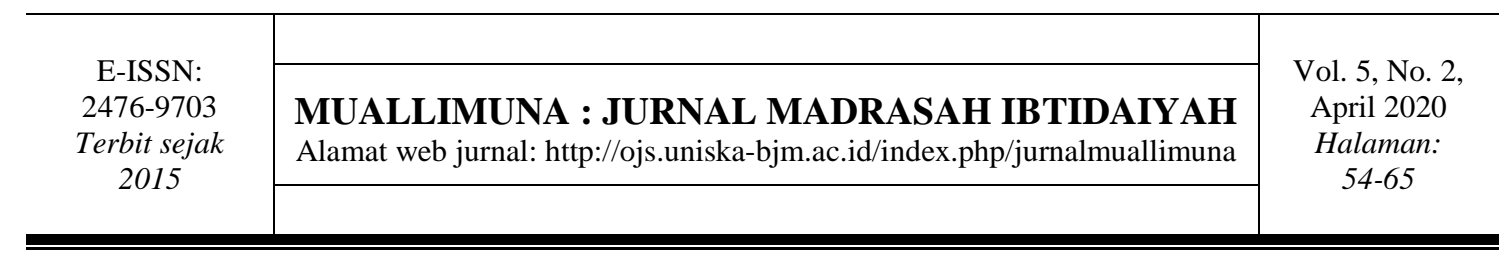

\title{
PENGEMBANGAN BUKU AJAR BERBASIS INFOGRAFIS PADA TEMA EKOSISTEM UNTUK MENINGKATKAN HASIL BELAJAR SISWA KELAS V SD
}

\author{
Haidhar Reizal $^{1}$, Agustiningsih ${ }^{2}$, Fajar Surya Hutama ${ }^{3}$ \\ 1,2,3 PGSD, Universitas Jember \\ 1hareizal@gmail.com, ${ }^{2}$ ningsihagustin83@gmail.com, \\ 2fajarsurya.fkip@unej.ac.id
}

\begin{abstract}
Abstrak: Penelitian ini menghasilkan produk berupa buku ajar berbasis infografis pada tema 5 ekosistem subtema 1 komponen ekosistem pada kelas 5 SD. Jenis penelitian yang digunakan adalah penelitian $\mathrm{R} \& \mathrm{D}$ (research and development). Kelayakan produk buku ajar berbasis infografis diukur berdasarkan validitas buku, efektivitas buku dan respons siswa. Subjek uji coba penelitian ini adalah siswa kelas VD SDN Jember Lor 01, siswa kelas VA SDN Jember Lor 02 dan siswa kelas V Ustman SDIT Harapan Umat. Metode pengumpulan data yang digunakan ialah validasi dan kueisioner. Berdasarkan hasil analisis validasi didapatkan persentase dari validator ahli sebesar 92,6\% dan dapat dikatakan sangat valid. Keefektivitasan buku ajar berdasarkan angket hasil belajar siswa didapatkan persentase sebesar $80 \%, 82 \%$ dan $84 \%$. Buku ajar infografis mendapat respons positif dengan persentase $100 \%, 100 \%$ dan $97,7 \%$. Berdasarkan hasil tersebut buku ajar berbasis infografis sudah memenuhi aspek untuk dapat digunakan sebagai buku ajar.
\end{abstract}

Kata Kunci: infografis, buku ajar, ekosistem

\section{INFOGRAPHIC BASED TEXT BOOK DEVELOPMENT IN THE ECOSYSTEM THEME TO IMPROVE STUDENT LEARNING OUTCOMES IN $5^{\text {TH }}$ CLASS ELEMENTARY SCHOOL}

Abstract: This research developed an infographic-based textbook on subtheme 1: ecosystem component of theme 5: an ecosystem in 5th grade of elementary school. The research type used $R \& D$ (research and development). Infographic-based textbook's properness measured by book validation, book effectivity, and students' responses. The subject of this research was $V$ grade students $D$ class from SDN Jember Lor 01, $V$ grade students B class from SDN Jember 02, and V grade student Ustman class from SDIT Harapan umat. This research used validation and questionnaire as data collection methods. From the data analysis, the percentage obtained from validator was 92,6\%, and it could be concluded as very valid. The infographic-based textbook effectivity based on student learning outcomes questionnaire, the percentage that obtained were $80 \%, 82 \%$, and $84 \%$. The infographic-based textbook got a positive response, with a percentage of $100 \%$, $100 \%$, and 97,7\%. From the result, an infographic-based textbook fulfilled aspect to be used as a textbook.

Keywords: Infographic, textbook, ecosystem 


\section{PENDAHULUAN}

Tercapainya tujuan pembelajaran di Indonesia tidak lepas dari peran kurikulum. Pemerintah Indonesia saat ini menerapkan kurikulum 2013. Permendikbud No. 67 tahun 2013 tentang Kurikulum SD bertujuan untuk membentuk siswa yang beriman, produktif, kreatif serta dapat membawa nama Indonesia dalam kompetensi global. Pembelajaran tematik dimaksudkan agar siswa dapat lebih mudah dalam memahami materi pembelajaran yang diajarkan guru. Penerapan pembelajaran tematik di SD perlu dipersiapkan dengan matang oleh guru, sehingga tujuan pembelajaran bisa tercapai.

Pemerintah Indonesia mempersiapkan buku siswa untuk mengefektifkan pembelajaran. Buku siswa terbagi dalam beberapa tema dan di setiap tema terintegrasi mata pelajaran yang saling berkaitan. Dalam implikasi pembelajaran tematik, sumber belajar tidak harus datang dari satu sumber. Sumber belajar yang hanya dari buku siswa dirasa kurang cukup. Oleh karena itu, guru dapat menyiapkan bahan ajar lainnya selain buku siswa. Guru dapat menyiapkan bahan ajar baru berupa suplemen khusus yang tidak hanya memuat materi pembelajaran bagi siswa, sehingga siswa dapat memahami konsep pembelajaran dan juga mencapai tujuan pembelajaran.

Tema kelima pada kelas 5 adalah ekosistem. Tema kelima terbagi menjadi 4 subtema salah satunya adalah subtema 1 "Komponen Ekosistem". Materi ekosistem yang diajarkan kepada siswa dianggap sulit dipahami karena pembelajarannya monoton karena kurang adanya inovasi dari guru (Lestari 2015). Konten dalam buku seperti gambar harus menarik, tulisan dalam buku juga harus komunikatif. Bahasa yang harus ditampilkan adalah bahasa yang lazim digunakan dalam bahasa komunikasi tulis bahasa Indonesia, selain itu bahasa harus sopan, halus, baik dan sesuai dengan kebiasaan atau dekat dengan siswa (Purnanto dan Mustadi, 2018). Berdasarkan observasi yang dilakukan oleh (Lailyn 2018) keterbatasan uraian materi membuat guru kesulitan dalam menjawab pertanyaan siswa yang tidak terdapat pada buku, sehingga guru sebagai fasilitator dapat menyediakan bahan ajar sebagai penunjang buku siswa yang ada. Bahan ajar tersebut berfungsi sebagai penunjang tercapainya pembelajaran.

Selama kegiatan pembelajaran, seorang guru dituntut selektif dalam pemilihan bahan ajar. Guru harus menggunakan bahan ajar yang efektif agar dapat menunjang pembelajaran di dalam kelas. Bahan ajar sendiri bersifat mandiri, menjelaskan tujuan instruksional yang akan dicapai, memotivasi dan mengantisipasi kesukaran siswa dengan menyediakan bimbingan belajar, memberi latihan yang cukup, menyediakan rangkuman, dan berorientasi kepada siswa secara individual (Octaviani 2017). Berdasarkan penjelasan tersebut dapat dikemukakan bahwa bahan ajar adalah materi pelajaran yang memberikan latihan pada siswa demi tercapainya tujuan pembelajaran.

Bahan ajar yang efektif dapat meningkatkan kemampuan siswa, sehingga kualitas pembelajaran juga lebih baik. Guru dapat menyesuaikan bahan ajar yang sesuai bagi siswa, salah satu jenis bahan ajar ialah buku ajar. Pengembangan buku ajar sebagai suplemen akan lebih efektif apabila dirancang oleh guru, karena guru lebih paham akan kondisi siswa di sekolah. Dalam meningkatkan pemahaman siswa dapat menggunakan buku ajar yang memiliki visual yang menarik. Menurut Susetyo, Bahruddin, dan Windarti (2015) penggunaan infografis terbukti efektif dengan hasil yang diperoleh dan juga infografis berpengaruh dalam daya ingat dan nalar siswa. Kondisi tersebut dapat dimanfaatkan guru untuk merancang buku ajar berbasis infografis untuk menunjang pemahaman siswa akan materi.

Infografis adalah teknik menyajikan informasi secara visual/grafis, sehingga 
mudah dipahami oleh pembaca (Saptodewo 2014). Penggunaan infografis diharapkan dapat mempermudah siswa dalam memahami materi. Masyarakat saat ini lebih tertarik pada informasi yang dikemas secara menarik dan kreatif tanpa mengurangi informasi yang disampaikan (Siregar, Sirumapea dan Ibrahim, 2018). Penyajian ragam visual yang terdapat dalam infografis dapat membuat siswa lebih mudah paham dan mengerti materi pelajaran yang disajikan. Infografis menyajikan gambar-gambar yang diharapkan membuat siswa tertarik untuk membaca dan gambar tersebut merupakan visualisasi materi pelajaran agar siswa mudah memahami materi. Penggunaan infografis sebagai media pembelajaran dapat berpengaruh terhadap prestasi belajar siswa pada ranah kognitif (Umami, Utomo dan Ashadi, 2016). Dikembangkannya buku ajar yang berbasis infografis dimaksudkan untuk mempermudah siswa dalam memahami materi. Digunakannya infografis akan membantu siswa dalam memvisualisasikan materi pembelajaran, sehingga lebih mudah diterima dan diingat oleh siswa.

Oleh karena itu, dilakukan penelitian pengembangan dengan judul "Pengembangan Buku Ajar Berbasis Infografis Tema Ekosistem Subtema Komponen Ekosistem pada Kelas V SD”. Berdasarkan latar belakang yang telah dipaparkan, maka dapat dikemukakan rumusan masalah sebagai berikut. (1) Bagaimanakah hasil pengembangan buku ajar berbasis infografis pada Tema 5 Ekosistem subtema 1 Komponen Ekosistem di kelas 5 SD? (2) Bagaimanakah efektivitas buku ajar berbasis infografis pada Tema 5 Ekosistem subtema 1 Komponen Ekosistem di kelas 5 SD?

\section{METODE}

Jenis penelitian yang digunakan merupakan penelitian pengembangan. Penelitian dan pengembangan memiliki tujuan utama bukan untuk merumuskan atau menguji teori, melainkan mengembangkan produk pembelajaran yang efektif untuk digunakan dalam proses pembelajaran di SD. Prosedur penelitian yang dipilih sebagai acuan dalam pengembangan buku ajar berbasis infografis adalah pengembangan $\mathrm{R} \& \mathrm{D}$ (research dan development) model Borg \& Gall. Model pengembangan R \& D yang terdiri dari 10 tahapan yaitu; (1) tahap potensi dan masalah; (2) tahap pengumpulan data; (3) tahap desain produk; (4) tahap validasi desain; (5) tahap revisi desain; (6) tahap uji coba produk; (7) tahap revisi produk; (8) tahap uji coba pemakaian; (9) tahap revisi produk; (10) tahap produksi masal. Penelitian ini dibatasi sampai tahap kesembilan karena adanya keterbatasan waktu dan biaya.

Tempat pelaksanaan pengembangan buku ajar berbasis infografis tema 5 ekosistem subtema 1 komponen ekosistem dilaksanakan di SDN Jember Lor 1, dan tempat penyebaran buku ajar berbasis infografis tema 5 subtema 1 dilaksanakan di dua sekolah yaitu, SDN Jember Lor 2 dan SD IT Harapan Umat.

Penelitian menggunakan 2 metode pegumpulan data yaitu metode validasi dan metode kueisioner. Instrumen pengumpulan datanya ialah berupa lembar validasi dan angket. Lembar validasi digunakan sebagai lembar penilaian kevalidan buku ajar berbasis infografis yang telah dikembangkan untuk diterapkan dalam proses pembelajaran dan untuk mendapatkan pendapat maupun saran terhadap pengembangan buku ajar berbasis infografis. Validasi dilakukan oleh 5 validator yaitu, 1 dosen PGSD sebagai ahli materi, 1 dosen PGSD dan 1 dosen Pendidikan Biologi sebagai ahli desain dan bahasa, dan 2 guru kelas $\mathrm{V}$ sebagai ahli materi. Kuesioner dilakukan dengan membagikan selebaran yang berisi pertanyaan yang terkait dengan penggunaan buku ajar yang telah diujikan. Instrumen yang digunakan berupa angket yang berisi pertanyaan terkait sumber belajar yang digunakan dalam proses pembelajaran. 
Data yang didapat pada penelitian ini selanjutnya dilakukan analisis. Data yang akan dianalisis pada penelitian ini adalah data validasi buku ajar, efektivitas buku ajar dan respons siswa. Bahan ajar dikatakan valid apabila buku ajar mendapat kriteria sangat valid berdasarkan tabel kriteria validitas menurut (Masyhud 2016) sebagai berikut.

Tabel 1. Kriteria Validitas

\begin{tabular}{ccl}
\hline No. & Kriteria Pencapaian Nilai & \multicolumn{1}{c}{ Tingkat Efektivitas/ Validitas } \\
\hline 1 & $80 \leq \mathrm{V} \leq 100$ & $\begin{array}{l}\text { Sangat valid atau dapat digunakan tanpa } \\
\text { perbaikan. } \\
\text { Cukup valid atau dapat digunakan namun } \\
\text { perbaikan kecil } \\
\text { Kurang valid, kurang efektif atau kurang tuntas, } \\
\text { perlu perbaikan besar, disarankan tidak } \\
\text { dipergunakan. }\end{array}$ \\
3 & $60 \leq \mathrm{V}<80$ & $\begin{array}{l}\text { Tidak valid atau tidak bisa digunakan. } \\
\text { Sangat tidak valid atau tidak bisa digunakan }\end{array}$ \\
4 & $40 \leq \mathrm{V}<60$ & $20 \leq \mathrm{V}<40$ \\
\hline
\end{tabular}

Berdasarkan data hasil pencapaian hasil belajar siswa, dapat ditentukan nilai keefektifan penggunaan bahan ajar Buku Ajar berbasis infografis Tema 5 ekosistem subtema 1 komponen ekosistem dikatakan efektif apabila $\geq 80 \%$ nilai uji kompetensi siswa memenuhi nilai kriteria ketuntasan minimal (KKM). Hobri (2010:45), mengemukakan bahwa untuk mengukur pendapat siswa selama proses pembelajaran dengan buku ajar berbasis infografis menggunakan angket respons siswa. Siswa dapat dikatakan merespons positif apabila percentage of agreement $\geq 50 \%$.

\section{HASIL DAN PEMBAHASAN}

\section{Hasil}

Penelitian yang dilakukan mengembangkan buku ajar berbasis infografis tema 5 Ekosistem subtema 1 Komponen Ekosistem pada kelas 5 SD. Pada tahap potensi dan masalah dilakukan studi pustaka, analisis materi dan analisis tujuan penelitian. Pada studi pustaka ditemukan bahwa pembelajaran ekosistem dirasa sulit dimengerti oleh siswa karena kurangnya inovasi guru terhadap bahan ajar ataupun media pembelajaran yang digunakan selama proses pembelajaran. Pada analisis materi dilakukan identifikasi terhadap materi yang akan disajikan. Pada analisis penelitian dirumuskan tujuan pembelajaran yang akan digunakan untuk proses pembelajaran.

Pada tahap pengumpulan data dilakukan penentuan bahan ajar yang dikembangkan yaitu buku ajar berbasis infografis. Selanjutnya dilakukan perancangan format yang akan disajikan pada buku ajar. Langkah berikutnya dilakukan perancangan tampilan buku ajar semenarik mungkin. Sebelum mendesain produk buku ajar berbasis infografis, terdapat beberapa hal yang harus ditentukan terlebih dahulu antara lain sebagai berikut.

\section{Menentukan judul buku ajar}

Berdasarkan pengkajian dan melihat permasalahan yang telah dipaparkan sebelumnya, diperoleh judul buku ajar yang akan dikembangkan yakni "Infografis Buku Ajar Tema 5 Ekosistem Subtema 1 Komponen Ekosistem Fokus Pembelajaran IPA" pada kelas 5 SD.

\section{Menentukan standar isi}


Standar isi yang digunakan pada buku ajar berbasis infografis disesuaikan dengan kurikulum 2013 pada tema 5 "Ekosistem" subtema 1 "Komponen ekosistem" di kelas 5 SD.

\section{Membuat isi buku}

Isi buku ajar yang dikembangkan berupa materi yang sesuai dengan buku ajar terbitan pemerintah yang diubah kedalam bentuk infografis. Buku ajar ini dikemas dengan penuh warna dan juga terdapat ilustrasi-ilustrasi yang menarik. Materi yang dikemas dalam bentuk infografis diharapkan dapat mempermudah pemahaman siswa.

Langkah selanjutnya ialah mengembangkan desain produk buku ajar. Desain buku ajar berbasis infografis dirancang menggunakan aplikasi Corel Draw 2019 menggunakan PC. Produk buku ajar yang dikembangkan dirancang dengan ukuran $20 \mathrm{x}$ $20 \mathrm{~cm}$. Buku ajar yang dikembangkan dalam penelitian ini memiliki beberapa bagian. Bagian-bagian tersebut akan dideskripsikan sebagai berikut.

a. Halaman sampul (cover)

Halaman sampul pada buku ajar berbasis infografis memuat identitas buku seperti judul beserta tema dan subtema, nama penulis beserta dosen pembimbing, kelas dan ilustrasi pendukung berupa penampakan alam yaitu gunung, padang rumput, pepohonan, sapi dan ilustrasi manusia. Ilustrasi yang dipilih untuk dimuat pada halaman sampul merupakan representasi isi buku yang dikembangkan. Tampilan halaman sampul pada buku ajar berbasis infografis dapat dilihat pada Gambar 1.

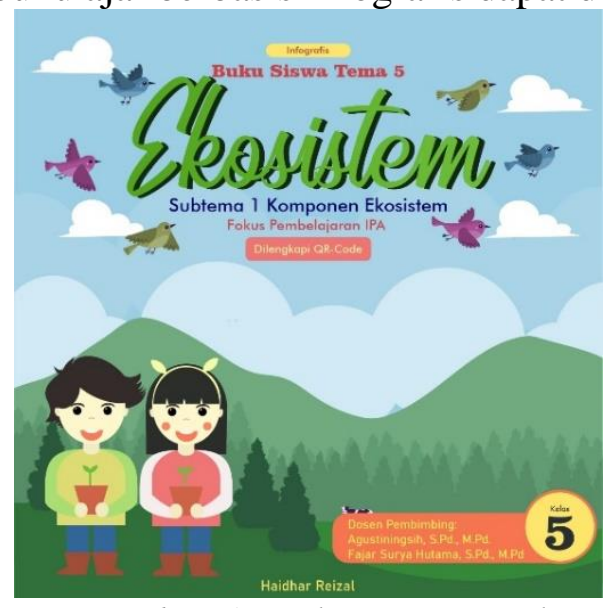

b. Informasi buku

Gambar 1. Halaman Sampul

Halaman informasi buku menampilkan tentang judul buku, informasi penulis buku ajar berbasis infografis, dosen pembimbing selama perancangan buku ajar berbasis infografis, informasi cetakan dan juga alamat redaksi. Tampilan informasi buku dapat dilihat pada Gambar 2. 


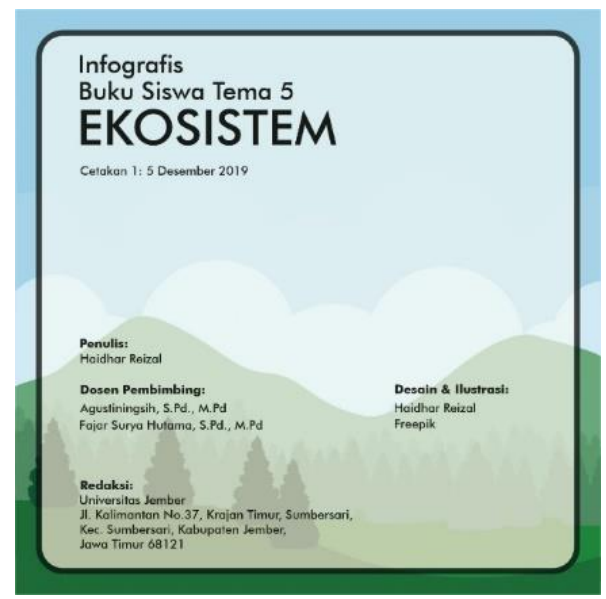

Gambar 2. Informasi Buku

c. Petunjuk penggunaan buku

Pada halaman petunjuk penggunaan buku terdapat petunjuk yang berisikan cara penggunaan buku ajar berbasis infografis. Terdapat beberapa penjelasan terhadap isi buku. Bagian petunjuk penggunaan dapat dilihat pada Gambar 3.

\section{d. Kompetensi dasar}

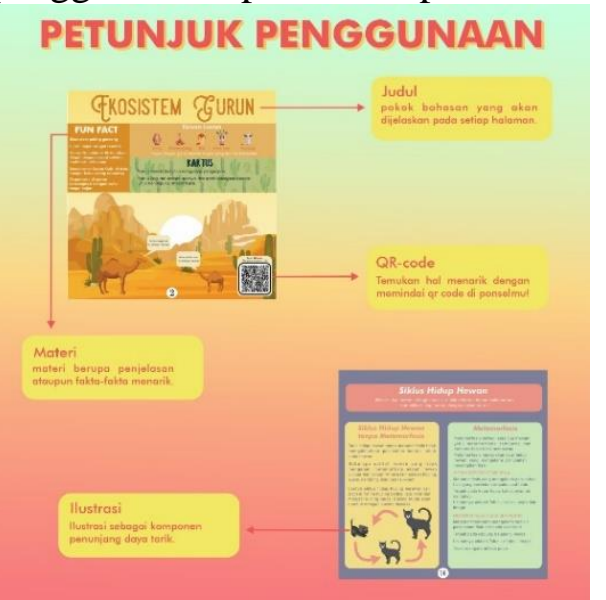

Gambar 3. Petunjuk Penggunaan

Halaman kompetensi dasar (KD) menjelaskan tentang acuan dalam pengembangan buku ajar berbasis infografis. Tampilan KD dapat dilihat pada Gambar 4.

\section{e. Daftar Isi}

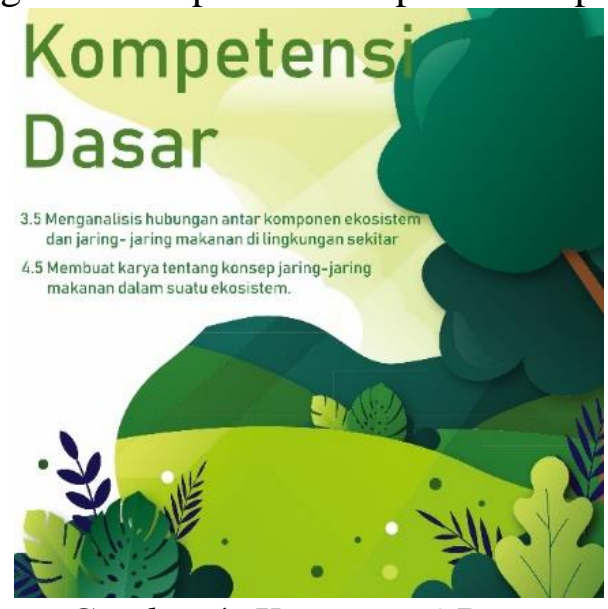

Gambar 4. Kompetensi Dasar 
Pada halaman daftar isi memuat nomor halaman setiap subbab. Subbab yang dimuat pada halaman daftar isi yaitu ekosistem, jenis jenis ekosistem seperti gurun, hutan hujan tropis, padang rumput, sabana, taiga, tundra, ekosistem air, ekosistem laut, sungai, penggolongan hewan berdasarkan makanannya, tumbuhan, penggolongan hewan herbivora, hewan, penggolongan hewan karnivora, siklus hidup hewan, metamorfosis kupu-kupu, metamorfosis capung, dan perubahan ekosistem. Tampilan daftar isi dapat dilihat pada Gambar 5.

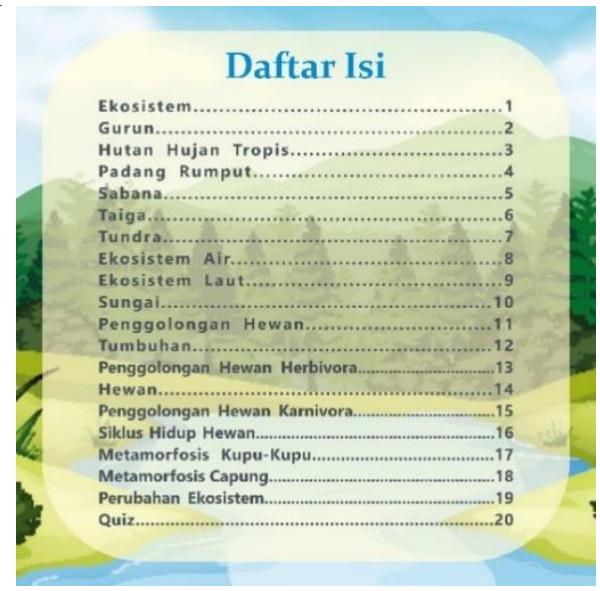

\section{f. Pembahasan materi}

\section{Gambar 5. Daftar Isi}

Halaman pembahasan materi merupakan isi atau materi yang terdapat pada buku ajar berbasis infografis. Halaman ini merupakan halaman pengembangan materi buku ajar siswa yang dipresentasikan dalam bentuk infografis yang mengacu pada kompetensi dasar. Tampilan halaman materi dapat dilihat pada Gambar 6.

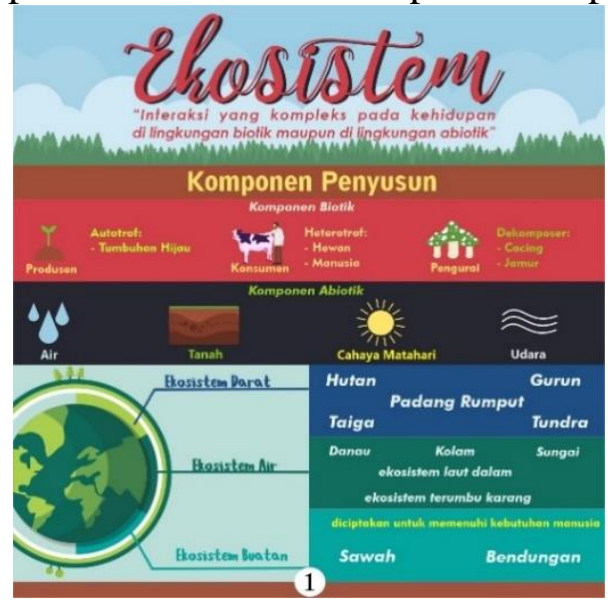

Gambar 6. Pembahasan Materi

g. Daftar pustaka

Pada halaman daftar pustaka berisi daftar bacaan dan referensi yang dimuat dalam buku ajar berbasis infografis. Tampilan daftar pustaka dapat dilihat pada Gambar 7 . 


\section{Daftar Pustaka}

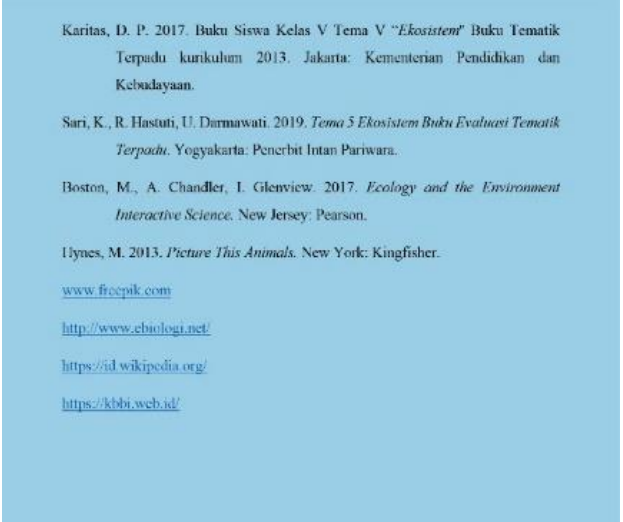

Gambar 7. Daftar Pustaka

\section{h. Glosarium}

Pada halaman glosarium memuat daftar kata sulit yang terdapat pada setiap halaman pembahasan materi. Halaman ini berfungsi untuk memudahkan pembaca dalam memahami kata-kata yang sulit dimengerti. Tampilan glosarium dapat dilihat pada Gambar 8.

\section{i. Sampul belakang}

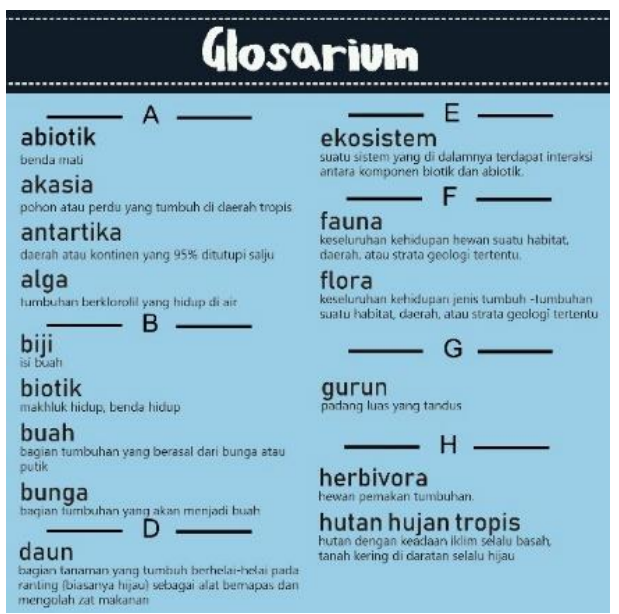

Gambar 8. Glosarium

Halaman sampul belakang memuat judul buku dan juga QR code yang terintegrasi pada akun instagram yang didesain dengan latar belakang gradasi warna biru yang sederhana. Tampilan halaman sampul belakang dapat dilihat pada Gambar 9. 


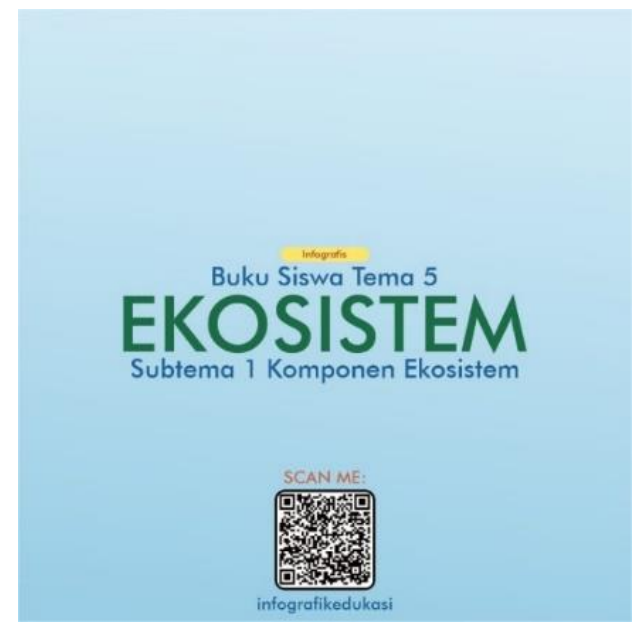

Gambar 9. Sampul Belakang

Pembahasan

Buku ajar yang dirancang telah memenuhi 3 elemen penting dalam infografis yang dikemukakan oleh (Kurniasih 2016) yaitu buku ajar berbasis infografis telah memuat materi berupa data, informasi dan pengetahuan sebagai isi, buku ajar dirancang menggunakan perangkat lunak yaitu Corel Draw 2019, dan buku ajar berbasis infografis memuat elemen visual seperti warna, grafis, dan ikon yang disesuaikan dengan target pembaca yakni siswa kelas 5 SD. Setelah dicetak, buku ajar akan divalidasi oleh validator. Validasi dilakukan untuk menilai kelayakan buku ajar yang dikembangkan. Validasi juga diperlukan untuk memperoleh masukan berupa kritik, saran dan komentar dari validator sebagai acuan untuk memperbaiki buku yang dikembangkan. Aspek yang dinilai dalam validasi ini adalah aspek kelayakan isi, kebahasaan, penyajian dan kegrafikan. Validasi dilakukan sebanyak 3 kali.

Hasil validasi pertama buku ajar berbasis infografis adalah $88 \%$. Menurut Masyhud (2016), nilai validasi yang berada pada rentang $80 \leq \mathrm{V} \leq 100$ dikategorikan sangat valid atau dapat digunakan tanpa perbaikan. Berdasarkan hal tersebut, dapat dikatakan bahwa buku ajar berbasis infografis dapat dikategorikan "sangat valid". Pada tahap validasi ini terdapat beberapa masukan dari validator. Beberapa masukan yang diperoleh ialah menambahkan nama pembimbing 1 dan 2 pada bagian cover, pemilihan font pada halaman 1 jangan tipis, meletakkan nomor halaman di bawah bagian tengah dengan background berwarna putih, mengganti warna kata funfact dengan warna putih, melakukan transparansi latar belakang halaman 8 agar tidak terlihat kaku, mengganti warna latar bentuk bulat dengan warna putih pada halaman 9, mengganti font pada kata metamorfosis, tulisan tidak perlu di highlight dan membesarkan ukuran font, menambahkan referensi berupa daftar pustaka untuk materi dan gambar.

Tahap selanjutnya adalah merevisi produk berdasarkan hasil validasi sesuai dengan masukan validator. Setelah melewati tahap revisi, buku ajar diuji coba kepada siswa. Tahap ini bertujuan untuk mengetahui efektivitas dan respon siswa terhadap buku ajar berbasis infografis. Mengukur efektivitas dapat dilakukan dengan memberikan post-test dan angket respon siswa di akhir pembelajaran. Uji coba pertama dilakukan di kelas VD SDN Jember Lor 01 menunjukkan bahwa 80\% dari jumlah keseluruhan siswa mendapatkan nilai di atas KKM. Menurut Masyhud (2016), hasil efektivitas yang berada pada rentang skor $80 \leq \mathrm{V} \leq 100$ dinilai memiliki keefektifan sangat tinggi. Hasil keefektifan buku ajar berbasis infografis tersebut dapat dikategorikan "sangat efektif". 
Pada siswa kelas VD SDN Jember Lor 01 keseluruhan siswa menjawab "ya" pada opsi angket yang memberikan respon positif pada buku ajar berbasis infografis mencapai $100 \%$. Sesusai dengan penelitian yang dilakukan oleh (Susetyo, Bahruddin, dan Windarti 2015), bahwa infografis dapat meningkatkan daya ingat siswa serta daya nalar siswa. Hal tersebut dibuktikan dengan nilai hasil belajar siswa yang di atas KKM. Pengaruh positif dikarenakan buku ajar berbasis infografis disajikan dengan visual yang menarik, sehingga meningkatkan minat belajar siswa. Hal ini sesuai dengan penelitian yang dilakukan oleh (Siregar, Sirumapea, dan Ibrahim 2018), bahwa penyajian informasi yang menarik dapat meningkatkan minat baca siswa.

Tahap selanjutnya yaitu tahap revisi buku ajar yang telah dilakukan uji coba pertama. Revisi buku ajar mengacu pada hasil validasi kedua yang dilakukan oleh validator. Validasi kedua dilakukan oleh 2 validator ahli dari guru kelas VD SDN Jember Lor 01 dan guru kelas VA SDN Jember Lor 02. Hasil validasi kedua buku ajar berbasis infografis adalah $86 \%$. Hasil tersebut menunjukkan bahwa buku ajar berbasis infografis dikategorikan "sangat valid". Pada validasi kedua ini terdapat beberapa masukan dari validator. Beberapa masukan tersebut adalah melengkapi bagian judul dengan tambahan subtema dan fokus pembelajaran, menambahkan materi tentang penggolongan hewan berdasarkan makanannya, menyajikan materi metamorfosis dengan benar.

Setelah melakukan validasi kedua maka dilakukan revisi berdasarkan masukan yang terdapat pada validasi kedua untuk diuji coba kembali. Uji coba selanjutnya dilakukan di kelas VA SDN Jember Lor 02 dan kelas V Ustman SDIT Harapan Umat. Data hasil uji coba di kelas VA SDN Jember Lor 02 menunjukkan 82\% siswa mendapatkan nilai di atas KKM. Selanjutnya hasil uji coba penelitian di kelas V Ustman SDIT Harapan Umat menunjukkan $84 \%$ siswa mendapatkan nilai di atas KKM. Berdasarkan analisis data yang diperoleh dapat diketahui bahwa keefektifan buku ajar berbasis infografis mencapai $82 \%$ dan $84 \%$ dan dapat dikategorikan "sangat efektif". Pada siswa kelas VA SDN Jember Lor 02 keseluruhan siswa menjawab "ya" pada opsi angket yang memberikan respon positif pada buku ajar berbasis infografis. Pada siswa V Ustman SDIT Harapan Umat diperoleh rata-rata jawaban "ya" pada opsi jawaban angket buku ajar berbasis infografis mencapai 97,7\%.

Tahap selanjutnya yaitu tahap revisi yang dilakukan dengan skala lebih luas. Revisi buku ajar dilakukan berdasarkan hasil validasi ketiga yang dilakukan oleh validator. Validasi ketiga dilakukan oleh 2 validator ahli materi dari dosen PGSD dan dosen Pendidikan Biologi FKIP Universitas Jember. Berdasarkan hasil analisis validasi oleh validator pada validasi ketiga dapat diketahui bahwa nilai validitas buku ajar berbasis infografis adalah 92,6\%. Berdasarkan hasil yang diperoleh buku ajar berbasis infografis dapat dikategorikan "sangat valid". Pada tahap ini buku ajar berbasis infografis mendapat beberapa masukan berupa memperbaiki redaksi buku untuk lebih spesifik, penambahan halaman untuk kata pengantar dan petunjuk penggunaan, merevisi bagian yang terjadi overlap warna, dan menambahkan fitur non konvensional.

Berdasarkan hasil analisis skor angket respon siswa menurut Khabibah, Kuswanti dan Suparno (2016) skor yang berada di rentang $81 \%$ - 100\% dari tahap uji coba menunjukkan bahwa buku ajar berbasis infografis dikategorikan mendapat respon "positif" dengan persentase respon siswa 100\% dan 97,7\%. Respon siswa dapat dikaitkan dengan efektivitas buku ajar. Menurut Hobri (2010), dari respon siswa dapat dilihat antusiasme siswa untuk mempelajari buku ajar. Semakin menarik buku ajar maka semakin besar rasa ingin tahu siswa untuk memahami materi yang disajikan. 
Kendala yang dialami pada penelitian pengembangan buku ajar berbasis infografis pada Tema 5 ekosistem subtema 1 komponen ekosistem di kelas 5 SD yaitu pada tahap perancangan buku ajar dikarenakan keterbatasan waktu dan dana saat penelitian. Pada tahap perancangan buku ajar, beberapa contoh ekosistem seperti tundra dan taiga yang tidak terdapat di Indonesia dirasa susah untuk diilustrasikan. Ragam hewan yang terdapat pada ekosistem tersebut beragam dan tidak terdapat di Indonesia. Gambar hewan dan ekosistem yang akan diilustrasikan sangat terbatas, sehingga digunakan ilustrasi yang mendekati penampakan aslinya. Hal tersebut berdampak pada siswa, sehingga harus diperkenalkan dan dijelaskan terlebih dahulu hewan tersebut dengan dimisalkan pada hewan yang terdapat di Indonesia.

\section{PENUTUP}

Hasil pengembangan pada penelitian ini berupa Buku Ajar Berbasis Infografis pada Tema 5 Ekosistem Subtema 1 Komponen Ekosistem di kelas 5 SD yang telah melalui tahap validasi. Validasi buku ajar berbasis infografis termasuk ke dalam kategori sangat valid dengan persentase validitas sebesar 92,6\%.

Efektivitas Buku Ajar Berbasis Infografis pada Tema 5 Ekosistem Subtema 1 Komponen Ekosistem di kelas 5 SD diketahui dari hasil belajar siswa yaitu di SDN Jember Lor 01 sebesar 80\%, SDN Jember Lor 02 sebesar 82\% dan SDIT Harapan Umat sebesar $84 \%$ dengan kategori sangat efektif. Keefektifan buku ajar berbasis infografis juga diukur berdasarkan respons siswa. Buku ajar berbasis infografis mendapatkan respons positif dari siswa SDN Jember Lor 01 dengan persentase respons positif sebesar 100\%, SDN Jember Lor 02 sebesar 100\% dan SDIT Harapan Umat sebesar 97,7\% atau dapat dikategorikan sangat baik. Berdasarkan hasil tersebut Buku Ajar Berbasis Infografis pada Tema 5 Ekosistem Subtema 1 Komponen Ekosistem di kelas 5 SD sangat efektif untuk dikembangkan.

\section{DAFTAR PUSTAKA}

Hobri. (2010). Metodologi Penelitian Pendidikan (Aplikasi Pada Penelitian Pendidikan Matematika). 1st ed. ed. Hatta Al-surkief. Jember: Pena Salsabila.

Kemendikbud. (2013). Permendikbud No. 67 Tahun 2013 Tentang Kurikulum SD. Jakarta: Kementrian Pendidikan dan Kebudayaan.

Khabibah, E. N., Kuswanti , N., \& Suparno, G. (2016). "Keefektifan Modul Berbasis Guided Discovery Pada Materi Respiratory System.” In Pros. Semnas Pend. IPA Pascasarjana UM, , 764-70.

Kurniasih, N. (2016). “Infografis.” In Komunikasi, Informasi Dan Perpustakaan Di Era Global, Jatinangor, 456-65. shorturl.at/evAWX.

Lailyn, A. N. (2018). "Pengembangan Buku Pendamping Tema 5 Subtema 1 Kelas 5 Sekolah Dasar." University of Muhammadiyah Malang. http://eprints. umm.ac.id/id/eprint/37988.

Lestari, T. (2015). "Pengaruh Penggunaan Media Diorama Terhadap Hasil Belajar Siswa Kelas V Pada Tema Ekosistem Di Sekolah Dasar.” JPGSD 3: 1114-23.

Masyhud, M. S. (2016). Metode Penelitian Pendidikan. 5th ed. ed. Zakiyah Tasnim. Jember.

Octaviani, Srikandi. (2017). "Pengembangan Bahan Ajar Tematik Dalam Implementasi Kurikulum 2013 Kelas 1 Sekolah Dasar.” jurnal pendidikan dasar 9(2): 93-98. 
shorturl.at/chxU6.

Purnanto, A. W., \& Mustadi, A. (2018). “Analisis Kelayakan Bahasa Dalam Buku Teks Tema 1 Kelas I Sekolah Dasar Kurikulum 2013.” Profesi Pendidikan Dasar 3(2): 101.

Saptodewo, F. (2014). "Desain Infografis Sebagai Penyajian Data Menarik.” jurnal desain 1(3): 193-98. shorturl.at/atwCS.

Siregar, S., \& Serepia, R, Sirumapea, A., \& Ibrahim, M. Y. (2018). "Buku Infografis “ Menjaga Kelestarian Lingkungan 'Untuk Menanamkan Sikap Peduli Lingkungan Pada Anak - Anak." jurnal sisfotek global 8(2): 40-48. shorturl.at/nxHO4.

Susetyo, H. R., Bahruddin, M, \& Windarti, T. (2015). “Efektifitas Infografis Sebagai Pendukung Mata Pelajaran IPS Pada Siswa Siswi Kelas 5 SDN Kepatihan Di Kabupaten Bojonegoro." jurnal desain komunikasi visual 4(1). shorturl.at/jHZ49.

Umami, M., Utomo, S., \& Ashadi. (2016). "Pengaruh Media Infografis Dan Poster Pada Pembelajaran Joyful Learning Terhadap Prestasi Belajar Siswa Ditinjau Dari Kemampuan Logika Pada Materi Pokok Kesetimbangan Kimia Kelas Xi Ipa Semester Gasal Sma Negeri Gondangrejo Tahun Pelajaran 2015/2016." Jurnal Pendidikan Kimia Universitas Sebelas Maret 5(3): 9-17. 